\title{
PENGARUH MODEL PEMBELAJARAN INKUIRI TERBIMBING BERBASIS ETNOKIMIA TERHADAP HASIL BELAJAR KIMIA SISWA KELAS XI DI MA AL-AZIZIYAH PUTRA KAPEK GUNUNGSARI
}

\author{
Hidayatussani", Saprizal Hadisaputra, Syarifa Wahidah Al Idrus \\ Program Studi Pendidikan Kimia, Universitas Mataram. Jalan Majapahit No. 62 \\ Mataram, NTB 83112, Indonesia. \\ * Coressponding Author. E-mail: hidayatussani98@gmail.com
}

Received: 7 Februari 2020

Accepted: 15 Mei 2020

Publish: 29 Mei 2020 doi: 10.29303/cep.v3i1.1687

\begin{abstract}
Abstrak
Penelitian ini bertujuan untuk mengetahui pengaruh model pembelajaran inkuiri terbimbing berbasis etnokimia terhadap hasil belajar kimia siswa kelas XI di MA Al-Aziziyah Putra Kapek Gunungsari Tahun Ajaran 2019/2020. Jenis penelitian ini adalah eksperimen semu dengan desain penelitian pre-test dan post-test Nonequivalen Control Group Design. Populasi dalam penelitian ini adalah seluruh siswa kelas XI MIA di MA Al-Aziziyah Putra Kapek Gunungsari. Kelas XI MIA 1 dipilih sebagai kelas eksperimen dan kelas MIA 2 sebagai kelas kontrol dengan teknik sampling jenuh. Kelas eksperimen diberikan perlakuan berupa pembelajaran dengan menggunakan model pembelajaran inkuiri terbimbing berbasis etnokimia sedangkan kelas kontrol dengan menggunakan model konvensional. Instrumen yang digunakan dalam penelitian ini adalah tes pengetahuan kognitif tipe pilihan ganda. Hasil uji hipotesis dengan menggunakan uji Mann Witney (Uji U) menunjukkan bahwa $Z_{\text {hitung }}<Z_{\text {tabel }}(1,41<1,99)$ pada taraf signifikan $5 \%$ yang berarti Ho diterima dan Ha ditolak. Jadi dapat disimpulkan bahwa tidak ada pengaruh model pembelajaran inkuiri terbimbing berbasis etnokimia terhadap hasil belajar kimia siswa kelas XI di MA Al-Aziziyah Putra Kapek Gunungsari tahun ajaran 2019/2020.
\end{abstract}

Kata Kunci: Inkuiri Terbimbing, Etnokimia, Hasil Belajar

\section{The Effect of Guided Inquiry Learning Based Ethnochemistry on Learning Outcomes of Class XI Students in MA Al-Aziziyah Putra Kapek Gunungsari Academic Year 2019/2020}

\begin{abstract}
This research aims to study the effect of ethnochemistry-based guided inquiry learning models on chemistry learning outcomes of class XI students in MA Al-Aziziyah Putra Kapek Gunungsari Academic Year 2019/2020. The research was quasi-experimental with Pre-test and Post-test Nonequivalent Control Group Design. The populations were all students of class XI MIA at MA AlAziziyah Putra Kapek Gunungsari. Class XI MIA 1 was chosen as an experimental class and MIA 2 class as a control class using saturated sampling techniques. The experimental class was given treatment by using ethnochemistry guided inquiry learning models whereas the control class was treated by conventional models. A multiple choice type cognitive knowledge test was used as a research instrument. The results of hypothesis testing using the Mann Witney test ( $U$ Test) show that $Z_{\text {hitung }}<Z_{\text {tabel }}(1.41<1.99)$ at a significant level of $5 \%$ which means that Ho is accepted whereas Ha is rejected. In conclusion, there is no influence of ethnochemistry-based guided inquiry learning model on chemistry learning outcomes of class XI students at MA Al-Aziziyah Putra Kapek Gunungsari Academic Year 2019/2020.
\end{abstract}

Keywords: Guided Inquiry, Ethnochemistry, Learning Outcomes 


\section{PENDAHULUAN}

Kimia merupakan cabang ilmu pengetahuan alam yang sangat penting karena sangat erat hubungannya dalam kehidupan sehari-hari. Namun, memiliki karakteristik materinya yang bersifat abstrak, melibatkan konsep-konsep, teori, hitungan dan penggunaan rumus (Chang, 2005). Hal ini menyebabkan sebagian besar siswa menganggap kimia sebagai mata pelajaran yang sulit dan membosankan. Selain itu, pembelajaran kimia di sekolah masih bersifat konvensional (berpusat pada guru). Hal ini berdampak pada rendahnya hasil belajar siswa dan sikap siswa terhadap pelajaran kimia negatif (Novrita, 2012).

Berdasarkan hasil observasi dan wawancara dengan guru mata pelajaran kimia di MA Al-Aziziyah Putra bahwa rendahnya hasil belajar kimia siswa di MA Al-Aziziyah Putra. Hal ini dapat dilihat dari data ringkasan hasil Ulangan Tengah Semester siswa kelas X MIA pada Tabel 1.

Tabel 1. Nilai Rata-Rata Ulangan Tengah Semester Mata Pelajaran Kimia Siswa Kelas X MIA di MA AlAziziah Putra Kapek Gunungsari

\begin{tabular}{cccc}
\hline No. & Kelas & $\begin{array}{c}\text { Nilai Rata- } \\
\text { rata }\end{array}$ & $\begin{array}{c}\text { Jumlah } \\
\text { siswa }\end{array}$ \\
\hline 1. & X MIA I & 58.71 & 31 \\
2. & X MIA 2 & 60.17 & 30 \\
\hline
\end{tabular}

Rendahnya hasil belajar siswa tersebut terkait dengan komponen-komponen pembelajaran kimia di Sekolah, diantaranya kurikulum, media, pendekatan, model dan evaluasi (Yupani, 2012). Proses pembelajaran yang sering digunakan di Sekolah yaitu menggunakan metode ceramah dan diskusi dua arah yang lebih terpusat pada guru. Pembelajaran kimia selama ini dimulai dengan guru menyampaikan materi, kemudian siswa diberikan tugas untuk dikerjakan di rumah (PR) sebagai bahan belajar di rumah yang kemudian dijawab bersama-sama dengan cara maju kedepan dan menjelaskannya. Selain itu, pembelajaran dengan praktikum jarang dilakukan. Siswa hanya sebagai penerima informasi, sehingga membuat siswa kurang berpikir atau dengan kata lain pembelajaran dirasakan kurang bermakna. Guru juga membiasakan siswa menghafalka beberapa konsep kimia, sehingga menurut guru siswa dapat menyelesaikan permasalahanpermasalahan dalam bentuk soal dengan baik. Partisipasi siswa dalam pembelajaran kimia yang rendah menunjukkan masih banyak siswa yang belum aktif mengikuti pembelajaran di kelas (Aftriani dkk, 2019).

Beberapa faktor penyebab rendahnya hasil belajar tersebut, maka sangatlah penting bagi pendidik untuk memahami karakteristik materi, siswa dan pemilihan model pembelajaran. Dengan demikian, pembelajaran akan lebih variatif, inovatif dan konstruktif dalam membangun siswa (Yupani, 2012). Tujuan pembelajaran dapat tercapai ditentukan oleh banyaknya faktor, salah satunya didukung oleh penggunaan model pembelajaran yang sesuai. Salah satu model pembelajaran yang mengeksplorasi pengetahuan awal siswa adalah model pembelajaran inkuri terbimbing berbasis etnokimia pada materi hidrokarbon.

Pembelajaran inkuiri merupakan pembelajaran yang berpusat pada siswa (Suyati, 2010). Model pembelajaran inkuiri melibatkan siswa secara maksimal dalam proses pembelajaran dan keterarahan kegiatan secara logis dan sistematis serta mengembangkan sikap percaya pada diri siswa (Syarifudin, 2018). Penerapan model pembelajaran inkuiri terbimbing adalah model pembelajaran yang menekankan pada pengalaman-pengalaman belajar yang mendorong siswa dapat menemukan konsepkonsep dan prinsip serta pembelajaran yang melibatkan beberapa metode pembelajaran untuk memberikan pengalaman belajar yang bermakna untuk siswa (Hayati, 2019).

Tujuan dasar inkuri yaitu mengembangkan kemampuan berpikir siswa secara sistematis, logis dan kritis atau mengembangkan kemampuan intelektual sebagai bagian dari mental, akibatnya dalam pembelajaran inkuri, siswa tidak hanya dituntut agar menguasai pelajaran, akan tetapi siswa dapat menggunakan potensi yang dimilikinya (Trianto, 2014). Murniningsih, 2016 menyatakan pembelajaran inkuiri yang berorientasi pada penyelidikan dapat meningkatkan hasil prestasi belajar siswa.

Sintaks model inkuiri terbimbing yaitu (1) Orientasi merupakan langkah membina suasana pembelajaran yang responsive, (2) Merumuskan masalah merupakan tahapan dimana siswa akan diajak untuk merumuskan masalah dengan proses berpikir, (3) Merumuskan hipotesis, hipotesis adalah 
jawaban sementara dari suatu permasalahan yang sedang dikaji, (4) Mengumpulkan data adalah aktivitas mengambil informasi dalam rangka menguji kebenaran hipotesis yang diajukan, (5) Menguji hipotesis adalah proses menentukan jawaban yang dianggap diterima sesuai dengan data atau informasi yang diperoleh dari upaya siswa untuk mengumpulkan data, dan (6) Merumuskan kesimpulan adalah proses mendeskripsikan temuan yang diperoleh berdasarkan hasil pengujian hipotesis (Hartono, 2014).

Pembelajaran kimia yang memperhatikan kearifan lokal merupakan salah satu hal yang perlu diperhatikan dalam pengembangan kurikulum di Indonesia, khususnya dalam kurikulum kimia ditingkat Sokolah Menengah Atas dan Lembaga Pendidik Tenaga Kependidikan (Sudarmin, 2015). Kearifan lokal adalah segala nilai, konsep dan teknologi yang telah dimiliki suatu bangsa sebelum mendapat pengaruh asing (Sedyawati, 1986). Sedangkan menurut Rahyono (dalam Atmaja, 2011) kearifan lokal merupakan butir-butir kecerdasan atau kebijaksanaan asli yang dihasilkan oleh suatu masyarakat budaya. Jadi kearifan lokal adalah segala nilai, konsep dan teknologi yang asli yang memang telah dimiliki oleh suatu masyarakat budaya yang diterapkan dalam kehidupan sehari-hari.

Model pembelajaran inkuiri terbimbing berbasis etnokimia (kearifan lokal) dapat menciptakan lingkungan belajar yang kondusif untuk mempermudah pembelajaran karena mengaitkan antara budaya lokal dan materi kimia (Wiyanto 2017). Pembelajaran inkuiri bermuatan kearifan lokal merupakan model pembelajaran yang bertujuan untuk menciptakan lingkungan-lingkungan untuk mempermudah pembelajaran dengan mengaitkan antara budaya dan materi kimia. Model pembelajaran inkuiri bermuatan kearifan lokal mengajak siswa untuk berinteraksi langsung dengan budaya lokal dan menggali ilmu pengetahuan yang ada pada budaya lokal tersebut (Imansari, 2017).

Berdasarkan latar belakang di atas, maka judul dari penelitian yang akan dilakukan yakni "pengaruh model pembelajaran inkuiri terbimbing berbasis etnokimia terhadap hasil belajar kimia siswa kelas XI di MA Al-Aziziyah Putra Kapek Gunungsari."

\section{METODE PENELITIAN}

Penelitian ini dimulai dengan tahap perencanaan penelitian dari bulan Mei 2019 dan pelaksanaan penelitian pada bulan Juli 2019 bertempat di MA Al Aziziyah Putra Kapek Gunungsari pada siswa kelas XI MIA tahun ajaran 2019/2020.

Jenis penelitian yang digunakan dalam penelitian ini adalah eksperimen semu bentuk Pre-test and Post-test Nonequivalent Control Group Design. Rancangan penelitian dilakukan pada dua kelas, yaitu satu kelas sebagai kelas eksperimen dan satu kelas lainnya sebagai kelas kontrol. Kelas eksperimen diberi perlakuan berupa pembelajaran dengan model pembelajaran inkuiri terbimbing berbasis etnokimia sedangkan pada kelas kontrol menggunakan model pembelajaran konvensional.

Variabel yang diamati dalam penelitian ini berupa variabel bebas dan variabel terikat. Variabel bebas merupakan variabel yang mempengaruhi atau yang menjadi sebab perubahannya (Sugiyono 2015), variabel yang dimaksud adalah model pembelajaran inkuiri terbimbing berbasis etnokimia. Varibel terikat merupakan variabel yang dipengaruhi atau menjadi akibat, variabel yang dimaksud adalah hasil belajar. Pembelajaran materi hidrokarbon pada kedua kelas.

Populasi dalam penelitian ini adalah seluruh siswa kelas XI MIA MA Al Aziziyah Putra Kapek Gunungsari yang terdiri dari dua kelas, yaitu XI MIA 1, XI MIA 2 yang seluruhnya berjumlah 58 siswa. Sampel yang digunakan sebanyak 2 kelas yaitu kelas XI MIA 1 sebagai kelas eksperimen dan XI MIA 2 sebagai kelas kontrol. Sampel ditentukan setelah uji homogenitas terlebih dahulu, sehingga diperoleh sampel yang homogen. Metode sampling yang digunakan dalam penelitian ini sampling jenuh.

Penelitian ini menggunakan instrumen berupa tes hasil belajar dalam bentuk pilihan ganda. Instrumen yang telah disusun terlebih dahulu diuji validitas dan reliabilitasnya. Uji validitas ada dua yaitu validitas isi dan validitas empiris. Validitas isi dengan menggunakan rumus Aikens'V sedangkan untuk validitas empiris menggunakan korelasi biserial. Uji reliabelitas soal dengan menggunakan KR-20 kriteria tertentu. Peningkatan hasil belajar akan diobservasi berdasarkan niai pre-test dan post-test dengan 
melihat sejauh mana peningkatan nilai yang dilihat dari selisih nilai pre-test dan post-test menggunakan $\mathrm{N}$-gain. Uji hipotesis dalam penelitian ini menggunakan uji-U, dilakukan setelah data diuji normalitas dan homogenitas terlebih dahulu.

\section{HASIL DAN PEMBAHASAN}

Penelitian ini bertujuan untuk mengetahui pengaruh model pembelajaran inkuiri terbimbing berbasis etnokimia terhadap hasil belajar kimia siswa pada materi pokok hidrokarbon. Penelitian ini dilakukan pada siswa kelas XI MA Al Aziziyah Putra Kapek Gunungsari tahun ajaran 2019/2020. Nilai rata-rata hasil pre-tes dan post-tes kelas sampel disajikan pada Gambar 1.

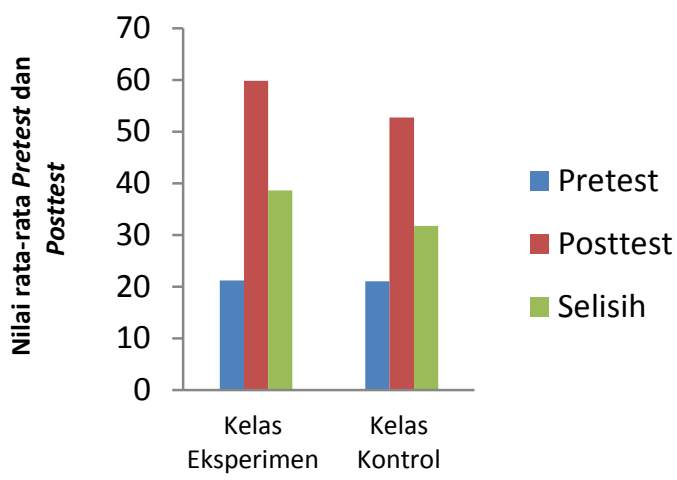

Gambar 1. Data Hasil Pre-test dan Post-test

Berdasarkan Gambar di atas menunjukkan bahwa peningkatan hasil belajar kelas ekperimen lebih tinggi daripada kelas kontrol. Hal ini karena model pembelajaran inkuiri terbimbing berbasis etnokimia memberikan kesempatan pada siswa untuk menemukan sendiri konsep yang ada pada materi yang dipelajarinya (Triyanto, 2014).

Materi yang dipelajarinya dikaitkan dengan fenomena-fenomena yang sering dijumpai siswa dalam kehidupan sehariharinya, sehingga siswa tertarik dan bersemangat dalam belajar serta lebih mudah memahami materi hidrokarbon (Pamungkas, 2017). Menurut Novak (2007) menyatakan bahwa rekontruksi konseptual dapat terjadi jika terjadi pembelajaran yang bermakna. Kearifan lokal merupakan kegiatan yang mentransfer sains asli (pengetahuan yang berkembang di masyarakat) menjadi sains ilmiah (Rahayu dan Sudarmin, 2015). Dengan demikian siswa menjadi lebih bersemangat, mudah memahami materi, dan lebih lama mengingat materi pelajaran.

Berdasarkan kualifikasi nilai raport kelas ekperimen dengan nilai rata-rata 59,80 termasuk kedalam kategori cukup sedangkan untuk kelas kontrol dengan nilai rata-rata 52,73 kategori kurang. Selain itu dilihat juga dari tingkat pemahaman siswa terhadap materi yang diberikan dapat diperoleh melalui besaran rata-rata $\mathrm{N}$-gain ternormalisasi $\langle\mathrm{g}>$ pada kedua kelas sampel. Kelas eksperimen lebih besar daripada kelas kontrol yaitu 0,49 dan 0,40 . Hal ini didukung oleh frekuensi data nilai $\mathrm{N}$-gain siswa dari kedua kelas sampel ditunjukkan pada Gambar 2.

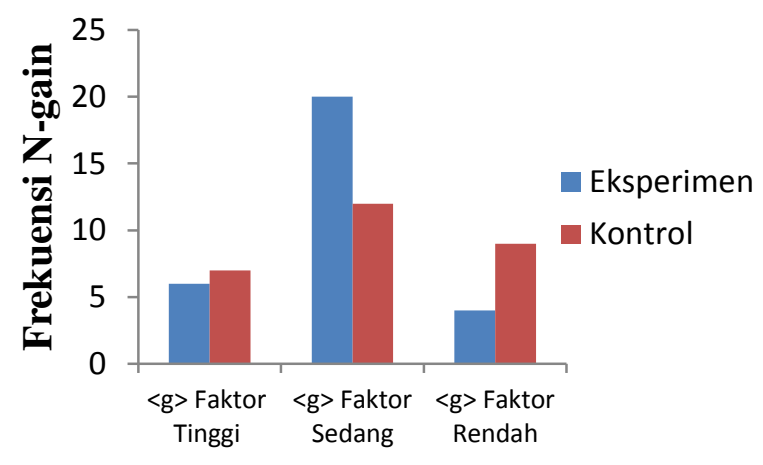

Gambar 2. Sebaran Frekuensi Nilai N-Gain Siswa

Berdasarkan Gambar 1.2 di atas menunjukkan bahwa siswa pada kelas ekperimen lebih optimal dalam memahami materi dibandingkan kelas kontrol. Meskipun pemahaman siswa pada kedua kelas dalam kategori belum memuaskan.

Berdasarkan hasil uji statistik data hasil

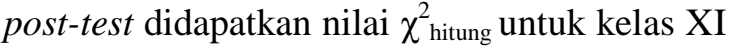
MIA 1 dan XI MIA 2 berturut-turut adalah 114,73 dan 176,84 kemudian keduanya dikonsultasikan dengan $\chi_{\text {tabel }}^{2}$ dengan taraf signifikan $5 \%(\mathrm{dk}=5)$ diperoleh $\chi_{\text {tabel }}^{2}$ sebesar 11,07 . Oleh karena kedua kelas memiliki nilai $\chi_{\text {hitung }}^{2}>\chi_{\text {tabel }}^{2}$ maka data hasil post-test diasumsikan tidak terdistribusi normal.

Uji homogenitas varians dihitung dengan menggunakan uji-F. Nilai $F_{\text {hitung }}$ yang diperoleh adalah 1,81 dengan nilai $\mathrm{F}_{\text {tabel }}$ pada taraf signifikan $5 \%$ sebesar 1,89 . Nilai Fhitung $(1,81)<$ Ftabel $(1,89)$ pada taraf signifikan $5 \%$ maka data yang diperoleh merupakan data yang homogen.

Pengujian hipotesis dilakukan dengan menggunakan uji Mann Withney (Uji-U). 
Diperoleh nilai $Z_{\text {hitung }}=1,41$. Nilai $Z_{\text {hitung }}$ dikonsultasikan dengan harga $\mathrm{Z}_{\text {tabel }}$ pada taraf signifikan $5 \%$ dan $\mathrm{dk}=58$ yaitu sebesar 1,99 .

Nilai $Z_{\text {hitung }}<Z_{\text {tabel }}$ hal ini menunjukkan bahwa uji hipotesis berada pada daerah penerimaan Ho yang menyatakan bahwa "Model pembelajaran inkuiri terbimbing berbasis masalah tidak memberikan pengaruh yang lebih baik daripada model pembelajaran konvensional terhadap hasil belajar kimia siswa kelas XI di MA Al Aziziyah Putra Kapek Gunungsari."

Hasil penelitian ini tidak sejalan dengan penelitian yang telah dilakukan oleh Wijayanthi dkk (2014) tentang penggunaan model pembelajaran inkuiri terbimbing berbasis kearifan lokal terhadap hasil belajar siswa, yang menyatakan bahwa hasil belajar mengalami peningkatan setelah diberi pembelajaran dengan model inkuiri terbimbing berbasis kearifan lokal.

Faktor-faktor yang menyebabkan tidak ada pengaruh penggunaan model, diantaranya ketidaksiapan sebagian siswa dalam melakukan proses pembelajaran inkuiri yang menuntut siswa untuk berperan aktif dalam proses pembelajaran sehingga siswa masih membutuhkan penyesuaian saat proses pembelajaran. Selain itu, siswa masih terbawa dengan metode yang biasa digunakan oleh guru di Sekolah. Siswa tidak terbiasa dengan belajar mandiri. Hal ini dapat dilihat pada proses pembelajaran siswa masih membutuhkan bantuan guru dalam memecahkan masalah. Siswa lebih cenderung melakukan pembelajaran secara individu bukan secara berkelompok, sehingga siswa yang memiliki minat belajar rendah sulit berinteraksi secara aktif. Siswa bergantung dan menyerahkan tugas kepada sebagian anggota saja yang seharusnya diselesaikan bersama semua anggota kelompok.

Masalah yang mendasar yang diduga menjadi penyebab ketidakberhasilan penelitian ini yaitu pelaksanaan sintak pembelajaran inkuiri terbimbing belum terlaksana dengan maksimal atau baik. Hal ini disebabkan karena jam pembelajaran kimia hanya sedikit yang terbagi dengan waktu yang lain. Salah satu kelemahan inkuiri terbimbing menurut Shoimin (2014) yaitu membutuhkan waktu yang lama.

Pertama, tahap orientasi semua siswa diharapkan dapat terlibat aktif dalam pembelajaran dengan kelompok. Namun, tidak semua siswa terlibat aktif dalam pembelajaran.

Kedua, tahap merumuskan masalah yang diharapkan siswa sudah mulai proses berpikir terkait dengan masalah yang diberikan. Namun, tidak semua siswa memiliki kemampuan dalam memecahkan masalah.

Ketiga, tahap merumuskan hipotesis yang diharapkan siswa bersama anggota kelompok merumuskan jawaban sementara dari permasalahan yang diberikan. Proses diskusi tidak berjalan dengan baik karena beberapa siswa dalam kelompok tidak terlibat aktif hanya sebagian kecil siswa yang mencoba merumuskan hipotesis.

Keempat, tahap mengumpulkan data dimana mengharuskan siswa untuk berperan aktif dalam mencari sumber informasi terkait materi yang dipelajari. Namun, tahap ini juga tidak terlaksana dengan maksimal, tidak semua siswa terlibat aktif dalam mencari informasi dan hanya satu atau dua kelompok saja yang terlihat kompak dalam berdiskusi.

Kelima, tahapan menguji hipotesis diharapkan mampu melatih siswa untuk berani mengungkapkan pendapatnya sendiri. Menurut Suherman (2008), belajar tidak cukup dengan hanya mendengar dan melihat tetapi harus dengan melakukan aktivitas (membaca, bertanya, menjawab, berkomentar, mengerjakan, presentasi, mengkomunikasikan dan diskusi). Pada tahap ini hanya satu dan dua siswa yang berani mengangkat tangan untuk memberikan sanggahan. Sementara siswa yang lain melakukan kegiatan lain seperti menyelesaikan pertanyaan yang belum selesai, mengobrol atau hanya diam mengamati saja.

Faktor lain yang menyebabkan tidak berhasilnya penelitian ini yaitu pertama, karena kelemahan dari model pembelajaran inkuiri terbimbing itu sendiri. (1) Pembelajaran dengan inkuiri memerlukan kecerdasan siswa yang tinggi. Bila siswa kurang cerdas hasil pembelajarannya kurang efektif, (2) Guru dituntut mengubah kebiasaan mengajar yang umumnya sebagai pemberi informasi menjadi fasilitator, motivator, dan pembimbing siswa dalam belajar, (3) Karena dilakukan secara kelompok, kemungkinan ada anggota yang kurang aktif, (4) Membutuhkan waktu yang lama dan hasilnya kurang efektif jika pembelajaran ini diterapkan pada situasi kelas yang kurang mendukung (Shoimin, 2014). 
Kedua, kurangnya sarana dan prasarana belajar. Sebagaimana yang dikatakan oleh Sanjaya (2010) bahwa kelengkapan sarana dan prasarana akan membantu siswa yang memiliki kemampuan lemah dan membantu guru dalam menyelenggarakan pembelajaran.

Ketiga yaitu sistem kegiatan pembelajaran di Pondok Pesantren itu sendiri. Menurut Mukhlis (2011) yaitu (1) Belajar kimia dirasa tidak ada gunanya selain hanya untuk ujian akhir nasional, (2) Kimia dirasa sulit karena pembelajaran hanya menonton tanpa adanya variasi dengan prakteknya, karena prakteknya dirasa sangat kurang, (3) Siswa cenderung malas bertanya pada guru karena diolok teman dan merasa tidak bisa sehingga menjadi malas bertanya, (4) Siswa lebih memilih untuk bertanya kepada temannya dikarenakan waktu bertemu dengan teman lebih banyak daripada dengan guru, (5) Partisipasi siswa selama pembelajaran cenderung hanya mencatat dan mendengarkan penjelasan guru, (6) Siswa sulit untuk mengajukan pertanyaan dan pendapat bahkan cenderung diam. Akibatnya interaksi guru dengan siswa berlangsung satu arah sehingga suasana pembelajaran menjadi membosankan dan (7) Siswa kurang dapat memperhatikan guru karena terlalu lelah dan bosan dengan banyaknya kegiatan yang ada asrama dan pergaulan yang sempit pada pondok.

\section{KESIMPULAN}

Berdasarkan hasil penelitian dan pembahasan, maka dapat disimpulkan bahwa model pembelajaran inkuiri terbimbing berbasis etnokimia tidak memberikan pengaruh yang lebih baik daripada model pembelajaran konvensional terhadap hasil belajar kimia siswa kelas XI di MA AlAziziyah Putra Kapek Gunungsari.

\section{SARAN}

Berdasarkan keunggulan dan kelemahan penelitian ini, terdapat beberapa saran untuk penelitan selanjutnya yaitu meskipun secara statistik tidak berbeda secara signifikan, namun dilihat dari peningkatan hasil belajar dan aktivitas belajar siswa kelas eksperimen lebih tinggi daripada kelas kontrol. Maka dalam pembelajaran pemakaian model pembelajaran inkuiri terbimbing berbasis etnokimia lebih baik daripada model pembelajaran konvensional.

\section{DAFTAR PUSTAKA}

Aftriani, D.N., Muntari, H.M., Anwar,Y.A.S. 2019. Pengaruh Pembelajaran Inkuiri Terbimbing pada Pelajaran Kimia terhadap Kemampuan Berpikir Kreatif Siswa Kelas XI IPA SMAN 2 Mataram. Chemistry education practice, 1(2), 1-6.

Atmaja, N.B. 2011. "Lokal genius dan kearifan lokal sebagai modal budaya dalam pendidikan karakter." Makalah disajikan dalam seminar nasional tentang pendidikan karakter berbasis lokal genius yang diselenggarakan oleh senat mahasiswa FIP Undiksha 2011.

Chang, R. 2005. Kimia Dasar. Jakarta : Erlangga.

Hayati, L. I Nyoman, L., Yunita, A.S.A. 2019. Pengaruh Model Pembelajaran Inkuiri Terbimbing dengan Metode Pembelajaran Terpadu kemampuan Berpikir Kritis. Chemistry Education Practice, 2(2), 1-7.

Imansari, M. "Analisis literasi kimiapeserta didik melalui pembelajaraninkuiri terbimbing bermuatan etnosains." Jurnal Inovasi Pendidikan.Vol.1.

No. 1: 2201-2211.

Murniningsih, I. M., Masykuri, M., Mulyani, $\begin{array}{ll}\text { B. 2011. "Penerapan } & \text { model } \\ \text { pembelajaran inkuri } & \text { terbimbing }\end{array}$ untuk meningkatkan sikap ilmiah dan prestasi belajar kimia siswa. Jurnal Inovasi Pendidikan IPA. Vol 2. No. 2: 177-189.

Nila, H. 2014. Pengaruh Penerap Mode Pembelajaran Berbasis Proyek terhadap Hasil Belajar Kimia SiswaKelas X SMAN 2 Mataram Tahun Ajaran 2014/2015.Skripsi S1. FKIP, Universitas Mataram.

Pamungkas, A., Subali, B., Linuwih, S. 2017. "Implementasi model pembelajaran IPA berbasis kearifan lokal untuk meningkatkan kreativitas dan hasil belajar siswa." Jurnal Inovasi Pendidikan IPA. Vol 3. No. 2: 110.

Rahmawati, H., Rise, H.V., Nurfina, A.S.2018. "Pengaruh implementasi model PBL berbasis kearifan local terhadap pemahaman siswa dan kemampuan berpikir kritis." Jurnal PMIPA ULMBanjarmasin. Vol. 1 No. 1: 1-25. 
Rahayu, S., Chandrasegaran, A. L.,Treagust, D. F., Kita, M., Ibnu, S. 2011.

"Understanding Acid Base

Concepts: Evaluating the Efficacy of a

Senior High School Student-

Centred Instructional Program in Indonesia." International Journal of Science and Mathematics Education. Vol. 9 No.6: 1439-1458.

Ridwan, N.A. 2007. "Landasan Keilmuan Kearifan Lokal." Jurnal Study Islamdan Budaya. Vol. 5 No. 1: 27-38.

Rohmadi, M. 2011. "Pembelajaran dengan pendekatan CEP (chemo enterpreneurship) yang bervisi SETS (science, enviroment, technology and society) guna meningkatkan kualitas pembelajaran." Jurnal Educatio. Vol.1. No. 1: 17-37.

Rosa, M.N. 2012. "Pengaruh sikap pada mata pelajaran kimia dan konsep diri terhadap prestasi belajar kimia." Jurnal Formatif. Vol. 2 No. 3: $218 \quad 226$.

Sanjaya, W. 2010. Strategi Pembelajaran Berorientasi Standar Proses Pendidikan. Jakarta : Kencana Prenadamedia Group.

Sedyawati. 1986. Lokal Genius dala Kesenian Indonesia. Jakarta: Dunia Pusaka Jaya.

Shoimin, A. 2014. 68 Model Pembelajaran Inovatif dalam Kurikulum 2013. Yogyakarta : AR-Ruzz Media.

Sudarmin. 2014. Pendidikan Karakter, Etnosains dan Kearifan Lokal: Konsep dan Penerapan dalam Penelitian dan Pembelajaran Sains.Semarang : CV. Swadya Manunggal.

Sudarmin. 2015. Model Pembelajaran Inovatif Kreatif(Model Paikem dalam Konteks Pembelajaran dan Penelitian Sains Bermuatan Karakter). Semarang: CV. Swadaya Manunggal.

Sugiyono. 2015. Metode Penelitian Pendidikan. Bandung : Alfabeta.

Suherman, E. 2008. "Model Belajar dan Pembelajaran Berorientasi Kompetensi Siswa." Bandung: Educare. Jurnal Pendidikan dan Budaya. Vol. 5. No. 2:1-10.

Suyati, R. D. 2010. Mendesains Model Pembelajaran Kimia. Yogyakarta: Graha Ilmu.

Trianto, A.B., Ibnu, B. 2014. Mendesain Model Pembelajaran Inovatif,Progresif dan Kontekstual. Jakarta : Prenada Group.

Utami, W, D., Wayan, D., Oktavia, S. 2017. "Pengaruh penerapan model inkuiri terbimbing terhadap hasil belajar dan keterampilan proses sains pada materi kelarutan dan hasil kali kelarutan". Jurnal Pendidikan. Vol. 1 No. 1: 1-10.

Wijayanthi, R. 2014. Konstruksi Pendidikan Karakter Kerja Keras. Surakarta: Skripsi FKIP Muhammadiyah.

Wuri, S. 2018. "Integrasi Nilai-Nilai Kearifan Lokal Dalam Pembelajaran untuk Menanamkan Nasionalisme di Sekolah Dasar". Jurnal Pendidikan. Vol. 1 No. $1: 1-10$.

Yupani, 2012. "Pengaruh model pembelajaran Predict-Observe Eksplain berbantuan materi bermuatan kearifan lokal terhadap hasil belajar IPA." Jurnal Pendidikan. Vol. 1 No. $1: 1-12$. 